DOI: $10.1515 /$ genst -2015-0004

\title{
APPROPRIATING A FEMALE VOICE: NICHOLAS BRETON AND THE COUNTESS OF PEMBROKE
}

\author{
REGHINA DASCĂL \\ West University of Timișoara, Romania \\ 4, V. Pârvan Blvd, 300223 Timișoara, \\ reghina.dascal@e-uvt.ro
}

\begin{abstract}
The sixteenth century author Nicholas Breton appropriates a female voice in many of his writings, among which Marie Magdalens Loue and The Pilgrimage to Paradise joyned with the Countesse of Penbrookes Loue feature prominently. The Countess of Pembroke, celebrated by Aemilia Lanyer in her Salve Deus Rex Judaeorum as a paragon of female religious devotion, is often associated in Breton's texts with Mary Magdalene. This paper will analyse some of the anxieties engendered by this appropriation of voice and of the Magdalene figure, anxieties that prove to be disruptive of Elizabethan gender hierarchies.
\end{abstract}

Keywords: female mystics, Mary Magdalene, penitence, ventriloquized female voices.

\section{Introduction}


My paper centres on the issue of ascribing gender to the voice of a certain text and I will try to illustrate the issue by identifying gendered voices in the writings of the $16^{\text {th }}$ century author Nicholas Breton. I will also look into his artistic intentions and the political and ideological underpinnings of his appropriation of an 'ostensibly female voice' in several of his texts (Trill 1998: 25-44). The appropriation of a female voice by a male author to such an extent that it appears to 'efface originary marks of gender' was defined by Elizabeth D. Harvey in Ventriloquized Voices: Female Theory and English Renaissance Texts as 'transvestite ventriloquism' (1992:16).

What could have been the male authors' ideological and political intentions in their ventriloquizing female voices? I am also concerned with the way Breton's texts depict the Countess of Penbrooke as a paragon of female penitence - modelled on Mary Magdalene, that archetype of penitence exposing in the process anxieties about the paradoxes and limitations of gendered roles in the $16^{\text {th }}$ century.

\section{Penitence in the $16^{\text {th }}$ Century and the Anxieties it Engendered}

As Protestantism became the institutionalized religion in $16^{\text {th }}$ century England confession and penitence played an increasingly significant part in the liturgy, but one can also see an increased emphasis on individuality and secrecy, because whereas penitence was an institutional requirement it also constituted a popular aspect of private devotional activity.

The act of penitence demands that the individual insert herself into a discourse that requires self-scrutiny and self-abasement; turning to the sombre teachings of John Calvin we find penitence rooted in the belief that we as 
individuals can do nothing that warrants or deserves God's favour, as the mind of man is so alienated from the righteousness of God that he cannot conceive, desire or design anything but what is wicked, distorted, foul, impure and iniquitous (Institutes of the Christian Religion quoted in Paul Delany 1969:35). The necessary acknowledgement of sinfulness coupled with an insistence upon the unworthiness of the individual produce a conception of the individual as self-negating and self-abasing. Natural self and natural will must be effaced or erased and replaced by an awareness of God's Spirit which enables the creation of a new will, a new being, a new self.

It is paradoxical, however, that this insistence upon self-denial seems to have played no small role in the production of subjectivity, and the development of the genre of autobiographical narrative is a good argument to substantiate this point. The self that is presented in these narratives is not unitary and singular but divided and more often than not a fissured or fractured self, and most importantly the individual is called upon to interrogate his consciousness in order to be assured of salvation (see Paul Delany, British Autobiography and Stephen Greenblatt's Renaissance Self-Fashioning). On the one hand, penitence seems to be gender-neutral in that all believers are called upon to explore who they are, the faults they may have committed, and the temptations to which they are exposed. Moreover, everyone is obliged to tell these things to other people, and hence to bear witness against her-/himself. Technologies of the self require a permanent hermeneutics of oneself (Foucault; Sennett 1981). On the other hand, Renaissance attitudes to women suggest that they in particular needed to repent, being more sinful than men due to their association with Eve and the lapsarian scenario. 
That this was so can be amply documented, but suffice it here to recall a notorious Act of 1543 - discussed by Eamon Duffy in The Stripping of the Altars (2005:432-433) - for the advancement of true religion with the purpose of rooting out superstition, ignorance, error and blindness and heresies, which forbade the reading of Tyndale's New Testament but also forbade the reading of the scriptures by most women either in public or in private (only noblewomen and gentlewomen being allowed to read them in private).

William Gouge in his well-known conduct book Of Domesticall Duties of 1622 quotes Ephesians 5:23: 'for the husband is the head of the wife even as Christ is the head of the Church' and makes it the epigraph of his Second Treatise, 'Of Common-Mutual Duties betwixt Man and Wife', in which he describes the role of the husband as nothing short of that of a priest and says that the husband should be to his wife 'her mouth to God when they two are together'. (114)

This hierarchical relation is confirmed in many Renaissance texts that promote penitential and confessional discourses as an appropriate form of expression for women, so that these discourses instructing women to maintain their subjected position when it came to the practice of penitence upheld the patriarchal order of Renaissance society (Trill 1998:27).

There is nevertheless a high degree of irony in this overall subordination of woman to man, and in particular in the fact that women were enjoined to be 'subject to their husbands' in spiritual matters, given that one of the issues that led to the break with the Papacy was resistance to the intercessory role of the priest. Furthermore, the need to maintain patriarchal order facilitated the focus on female penitence only to obscure the feminization of men in relation to 
Christ, since in the next verses of Ephesians 5, 25-27, all believers are referred to as 'the bride of Christ' - but this would have been too disruptive of Renaissance hierarchies to be recognized or commented upon.

But there is a further paradox that the development of the "hermeneutics of the self' reveals: the stress laid on woman's generic sinfulness was no doubt negative and highlighted her difference and separation from God, but on the other hand, features constructed in most cultures as feminine were precisely those that any individual was encouraged to attain in order to be closer to God, and this situation later proved to be an opportunity for women, opening up a space of creativity and self-fashioning for them.

As Toril Moi remarks, female mystics, religious women writers such as Margery Kempe, Julian of Norwich, or Birgitta of Sweden, insisted on selfinflicted abjection modelled on the image of the suffering Christ, and this paradoxically enabled them to open up a space where ther own pleasure can unfold' (1985:137). Such women experimented with wresting discourse and language from under the dominion of men, and the topos of humility that not only secular women authors but also nuns and female mystics used expressed the incompatibility of their language with that of men, while also proclaiming their inalienable right to invent a different tongue. Mary Magdalene became a paradigm for this subversive side of humility, and her politically charged potential to lead, to impose sacerdotal authority could not be missed (RégnierBohler 1992:482).

\section{Mary Magdalene - the Composite Saint}


The mediaeval Mary Magdalene is a palimpsest of several Maries: Mary of Bethany, sister to Martha and Lazarus (Luke 10 and John 11); Mary, who is exorcised by Christ of the seven demons, the first woman healed by Him (Luke 8); the first witness of the resurrection, present at the crucifixion and the empty tomb (Mark 15 and 16); she is also the unnamed woman who anoints Jesus' head with precious oils (Matthew 26; Mark 14, John 12) and the unnamed 'sinner' who washes Christ's feet with her tears and then wipes them with her hair in Simon the Pharisee's house (Luke 7). She is also at the centre of that epistemological paradigm shift recounted in John 20, where she speaks to the resurrected Christ before the empty tomb and recognizes the Rabuni in Him whom she initially takes to be a gardener. This too is where He addresses her with the words noli me tangere, thus separating sacred space and time from phenomenal time and space, the time when she could touch Him from a new time when the believer is enjoined to perceive Jesus with an Augustinian oculus mentis, a spiritual eye and not a bodily one (Badir 2009:76). Gregory the Great conceptualized this composite figure in his homily on Luke's Gospel delivered in Rome in 591 on the Friday after Holy Cross Day (14 September), thus consolidating this palimpsestic identity of the saint in question that has remained practically unchanged up to our own days despite various theological interventions, such as that of 1969 when the Catholic Church attempted to unburden the historical character of the Magdalene of its legendary accretions. The 'legendification' process had started in the $9^{\text {th }}$ century by conflating Mary Magdalene with Mary of Egypt and thus endowing her with extreme ascetic characteristics, and later on turning her into an apostle and preacher and crediting her with missionary zeal for Christianizing pagan Provence and 
Burgundy, where she performed a long string of miracles, such as miraculous healings, raisings of the dead, and bestowing the gift of fertility and motherhood. Katherine Ludwig Jansen remarks how over time her patronage of maternal and domestic issues became crucial for this saint (Jansen 2000:294303). According to legend she died at Aix and her relics were taken to the abbey of Vézelay in the mid- $11^{\text {th }}$ century, where she continues to work miracles. Towards the end of the $13^{\text {th }}$ century her relics were moved to the Church of St Maximin in Aix-en-Provence, where pilgrims and emperors, saints such as Birgitta of Sweden and great men of letters such as Petrarch venerated her (Schaus 2006:531-534). In the $11^{\text {th }}$ century, she also became an icon of monasticism by combining an active life committed to the communal good with the ideal of a contemplative life; in the $12^{\text {th }}$ century she was adopted as the patron saint of Provence, becoming a real apostolorum apostola. Mary Magdalene's privileged status as a preacher of the Resurrection not only makes her a symbol of the enhanced significance of the feminine in Christianity but also renders her a politically charged icon for the authority of women.

As Pierre Nora concludes, Mary Magdalene can be considered a true lieu de memoire, a locus of memory protecting the past while at the same time reimagining it and giving it new life in the present (Nora 1996:7).

\section{Text, Voice and Gender in Breton's Work}

It is a composite figure such as this who is invoked in a text attributed to Breton, Mary Magdalens Loue, in which the author stresses her significance as a model of penitence to be imitated by both male and female readers. She is exemplary in her recognition of her sins, her capacity to repent, her self-abasing 
tears and her desire to be with the Lord. At times the author seems to be aware of the potential objections to his placing a woman in this kind of prominent exemplary position: "Mary was a woman and shall men follow women?", but then his anxiety is dispelled by the desire for spiritual advancement: "why her happiness came from God, and shall not wee follow her to her happiness?", and in order to attain "the blessings of the soule" he urges his readers: "let us watch with Mary, walke with Mary, and weepe with Mary”.

While this prose work is generally only attributed to Breton, there is ample textual evidence that tips the scales in favour of his authorship, since in many of his writings he constructs images of the Countess of Pembroke in which he repeatedly associates her with Mary Magdalene, 'her brother's chief mourner'; yet his use of this parallel and also his appropriation of her name and voice target far larger issues than her relation to her brother, and what makes this appropriation very interesting is the fact that Breton reinforces the link between the language of penitence and the female voice (Trill 1998:28).

Only two of his texts on this subject are dedicated to male patrons and narrated in a male voice, while five are dedicated to women patrons and narrated in a female voice. So we have Divine Considerations of the Soule and Bretons Longing (dedicated to Sir Thomas Lake and to Lord North) and, with female dedications, The Pilgrimage to Paradise joyned with the Countesse of Penbrookes Loue, A Divine Poem divided into two parts. The Ravished Soul and the Blessed Weeper, Auspicante Jehova, Maries Exercise, all dedicated to the Countess of Pembroke, The Soules of Harmony dedicated to Lady Sara Hastings, and The Countesse of Penbrookes Passion, which was dedicated in manuscript to the Countess but to Lady Mary Houghton when published. 
How do these texts differ from each other and what part does gender play? Those spoken in a male voice and aimed at a male audience are more impersonal and abstract, with less reference to the experience of the speaker: they do speak about repentance and the need for penitence, but these are announced to the audience and morally commended rather than actually being lived and experienced. In Bretons Longing the first-person narrator identified with Breton by the title attempts to define love and the role of male speakers in approaching God. These speakers are presented by occupation and social position: the worldly prince and the worldly 'councellor', the soldier, the worldly scholar, the poet 'with his fictions', the worldly lawyer, the cosmographer, the astronomer, the worldly merchant, physician, musician, politician, the traveller, the painter, the lover, courtier, farmer, sailor, the worldly preacher - they are all very busy fulfilling their worldly duties but God has no place in their thoughts, and the speaker adopts the moralist's stance, without for a moment examining his own conscience. Bretons Longing does not focus upon Breton as speaker, or Breton as penitent; rather, the need to repent is projected outwards onto other characters so that the self is almost absent from the account (Trill 1998:29). Although the text finds all to be sinners, the speaker focuses on his own sins only at the end of the poem: "But, Oh vnworthy eye of such a sight; And all vnworthy heart of such a loue; / Vnworthy loue, to long for such a light; Vnworthy longing such a life to prooue; / But, ah wretched sinfull creature. How should the corrupted nature / Of this wicked heart of mine." Even in the more personal accompanying poems Solus in toto laudandus Deus and What is Loue we do not see the speaker presenting his own feelings or articulating his desire for or experience of divine 
love; yet again, with a moralistic tone, he opposes those who indulge in love for worldly beings or things: "What shall I say? but "tis beyond my saying. / And say but this, as I haue said before. That Loue is God, and I can say no more."

Breton seems particularly frustrated by not being able to articulate divine love; it is inexpressible, ineffable, and although is it recognized as a trope of the Renaissance that experiences of the divine are ineffable, it seems, as Trill remarks, that they appear to indicate that especially in a male voice it is so (30).

In the Soules Harmony, dedicated to Sarah Hastings, the speaker adopts a highly personal tone and speaks about her unworthiness, repenting of her sins: "And when, againe, the act of sinne is past. And that thy grace doth call me backe againe: Then in my teares I runne to thee as fast./ And of my sinnes, and of my selfe complayne. / What can I doe, but cry, Sweet Jesus, saue me / For I am nothing, but what thou wilt haue me." All attention is focused upon the speaker and her genuine act of penance: "Let my soules teares thy glorious mercy moue / To make me feele, how faith may be beloued;" In the impassioned tone of the speaker crying out to God we can see that fervent desire for self-abasement that is so crucial to the longed-for closeness to God.

As Elizabeth Harvey aptly observes in her Ventriloquized Voices, in male appropriations of feminine voices we can see what is most desired and most feared about women and why male authors might have wished to occupy that cultural space, however contingently and provisionally (32).

The Pilgrimage to Paradise joyned with the Countesse of Penbrookes Loue (1592) is dedicated to the Countess and examines the way two characters overcome the temptations and trials of earthly existence in their desire for 
spiritual happiness. In Breton's dedication to Lady Penbrooke, not unlike in his dedication to The Blessed Weeper, we can read that she served as Breton's personal Magdalene, a model of self-reflection and stillness for the production of his own godly words, and Magdalene's haunting presence makes the speaker feel Magdalene-like, provoking him to reach out and reconstruct his own experiences (Badir 2009:114).

In The Pilgrimage to Paradise the male pilgrim embarks upon an actual physical journey, which starts in a forest that is somehow reminiscent of the opening of Dante's Commedia and of his feeling led astray and lost (smarrimento): "A forest, ful of wild, and cruell beastes / The earth vntilde, the fruit vnhappines. / The trees all hollow, full of howletes nestes. / The aier vnholsome, or so foule infected". The pilgrim's senses come under assault from various temptations and he has to overcome the seven deadly sins. He meets various other pilgrims and often enters into debate with them, he travels across seas, enters a university town, attends a court, witnesses victorious battles and terrible defeats and learns his lesson about the best way to approach God and about how arduous and difficult the journey is, but he proves steadfast and as he keeps to the straight and narrow way he will eventually find the true church and enter paradise: "The gate, is Grace, Contrition, is the key, The locke, is loue, the porter, Penitence.../ Where humble faith, must heauenly labour stay. Till pity talke with vertues patience: / While angels sighes, the sinners waie deuise. To haue his entraunce into paradise." Although the need for penitence is often invoked we never see him engaging in it, either in public or in private.

The Countess of Penbrookes Loue, on the other hand, emphasizes private penitence and enclosedness within the closet. It starts with an array of 
characters who try to find out what the Countesse desires and what would make her happy, only the context is totally different as she undertakes no journey pointing to distinct gender roles: she within her domestic realm, the male traveller engaged in public conversations she remains within her house and court and the 'The worlde came in'; the discourse focuses upon her intimacy with Christ, her pious nature, her penitence, grace and forgiveness. Elaborating on many instances of the 'vanitas vanitatum' motif - "What is the worlde? but euen a woful thing. / What thing is man? a clodde of miry claie / Slime of the Earth, a slaue to filthie sinne", she turns to articulating her love of Christ, her utter dependence upon Him, and we can feel her turmoil and the intensity of her feelings. Although she cannot be truly described as a mystic Breton assigned her this status in his works. She is presented as desiring and close to achieving the loss of subjecthood, the disappearance of the subject/ object opposition that is at the core of the mystic (Irigaray 1985:136).

Christ is carefully constructed as her lover in terms ascribed to the lady in the Elizabethan sonnet sequences: "Thy face my Loue, is fairer then the sunne: / Thy beauty sweete, is brighter then the daie: / Thy shining light before the world begunne. [...] No, my sweete loue, let this poore soole of mine,/ Neuer haue life, but in that loue of thine. / One precious droppe of thy pure oill / Pouer downe, sweete loue into my wounded hart: / And to my faith, to turn thy loving face. That from thy fauour I maie neuer part: / Looke on thy Mary with her bitter teares. / That washt thy fieete and wipte them with her heares." We have here an example of the 'sexualization' of language - a characteristic of the mystics in particular - as they shared a painfully acute awareness of both the power of their discourse and the inability of logos to capture their inner 
experiences. Paradoxically, this is a language that makes room for the body in the spiritual vocabulary: "the feminization of language resulted in the invention of a new vocabulary that expressed the Absent through the extreme presence of the word" (Régnier-Bohler 1992:482).

Yet the intricacy of the textual voice and its association with gender is complicated by the three dedications that preface the book. Breton's dedications construct gender-specific audiences. Penbrooke is portrayed as speaking subject but Breton's dedicatory address does not invite her to read her own meditations and derive 'narcissistic pleasure' by identifying herself with his depiction of her meditations; rather, he would like to focus her attention upon the 'poeticall discourse of a poore pilgrims travels' and entreats her 'to let the poore pilgrimne that seeketh Paradise find heauen the better by your favour' (Trill 1998:33).

The construction of the audience of The Countesse is designated male by two methods: firstly, through the dedication to the Gentleman Students and Scholers of Oxforde, and secondly, by the presence of an unseen male narrator reporting her meditations within the poem itself. In both instances the male audience of one are invited to derive voyeuristic pleasure in observing Penbrooke's private meditations. Penbrooke is trapped within an almost mystical discourse, thinking that everyone has left, but he unseen remains; she is definitely unaware of his presence and the narrator intervenes only twice with minor comments, whereas the bulk of the text is presented as her own words. The eroticism of this situation is clear despite the religious subject of the poem and the content is sexualized by the voyeurism of the narrator (Trill 1998:33). She is thus constructed as an object of male desire, a spectacle to be looked at, 
an object to be desired, investigated, pursued and controlled and ultimately possessed by the male subject (Lauretis 1989:99).

The audience here is cross-gendered as the speaker of the text is of the opposite sex to that of the imagined readers.

Breton's disclaimer in his dedication that the 'weak discourse' of her meditations falls short of her worthiness to acquaint 'the honest mindes of vertuous dispositions, with the heauenly Meditations, of an honourable Lady, the weake discourse whereof, farre short of her worthines,' should not be taken, I think, as a mere convention but as an indication of Breton's inability to articulate her experience. He is an outsider and cannot fully represent her: he comments very briefly on her abundant tears and her contorted body, he can only register some physical reactions, but her inner experience, the meaning of the signs he registers, is lost on him.

John Case's prefatory address to Breton concludes as follows: "Your wit, pen and art therein sounde well together. The song is sweete, the ditty sweeter, but that rare Phoenix is the sweetest Phoenix, whom your wit, pen and art can but well shadow with all your Muses: for as an image is but an image, and the tincture of any thing is not the substance thereof, so the colours of her honours are in your booke, but the life of her virtue is in her selfe." (my emphasis). A clear split is operated here between male representation and female experience. It is Breton's clear intent to think highly of Penbrooke's capacity for self-abasing and denial since only emulation of these, he seems to imply, will obtain the bliss of intimacy with Christ. This is reminiscent of Petrarch's Latin version of the story of Griselda that crowns the tenth day of Boccaccio's Decameron. Petrarch says that he is not recounting the incredible 
sufferings of Griselda at the hands of the marquis, the compulsive tester, to urge other women to follow her example; rather it is to enjoin all Christians to emulate her qualities of endurance, patience and devotion. However, Breton is unable to represent Penbrooke's self-abasement, and what is hinted at here is that men's overarching concern with things pertaining to the public world hampers them from experiencing the comfort and happiness that the female voice can achieve; therefore, what he can do is to appropriate a female voice. It is Penbrooke's voice that he appropriates to articulate penitence because her major literary work was her translation of the Psalms, which played a prominent role in Protestant liturgy, as they were central to the articulation of penitence in the $16^{\text {th }}$ century and were recommended for daily reading, representing a crucial discourse in the development of autobiographical writing and ultimately in the production of subjectivity (Trill 1998:37).

"The Sidney Psalms" or "The Sidneian Psalms" - replacing the earlier translations made in Edward VI's reign, which were found to be deficient exerted a powerful influence on the development of English poetry in the late $16^{\text {th }}$ century and throughout the $17^{\text {th }}$ century. Mary Sidney finished Philip's translation of the Psalms (cut short by his untimely death on the battlefield), rendering Psalms 44-150 in an impressive array of verse forms, displaying a vivid imagination. She used the 1560 Geneva Bible and commentaries by John Calvin and Theodore Beza and as she was quite a competent theologian she was not shy of disagreeing with Calvin on several minor points. A copy of the completed Psalms was presented to Elizabeth I in 1599. John Donne wrote a poem celebrating them and calling Philip and Mary Sidney: "this Moses and 
this Miriam" who provided a model for English religious verse: "They shew us Islanders our joy, our King,/ They tell us why, and teach us how to sing".

\section{Conclusion}

Breton has a great admiration for religious poetry, but then, like Philip Sidney, he regards the Psalms as the highest form of poetry and often refers in his poems, particularly in Bretons longing, to the difference between the wayward poet, the secular poet with 'his fictions and his fancies', and the 'godly poet': "And such a Poet as the Psalmist was, Who had no minde but on his maister's loue. / Whose Muses did the world in musique passe. That only soong but of the soule's behoue. / In giuing glorie to the God aboue, Would all worlde's fictions wholly laye aside. / And onely long but with the Lord to bide".

His inability to represent his longing is not then only a matter of convention. His representation of penitential discourse suggests that men in their inability to cry, to interrogate themselves or to abase themselves are unable to achieve this intimacy with God (Trill 1998:39), but he also admits in the same breath that as a poet he cannot measure up to Mary Sidney: he has not been able to achieve what Penbrooke has with her translation of the Psalms.

Ventriloquism of female voices may, on the one hand, imply marginalization, erasure and silencing of the woman, thus reinforcing the teachings of Paul (I Corinthians 14:34; I Timothy 2:12) and revealing the limitations imposed on female expression, as Elizabeth Harvey suggests in Ventriloquized Voices, yet it also reveals the limitations of male expression in the spiritual realm. In addition, it calls into question deep-seated male anxieties 
about women's sacerdotal authority combined with the felt need to exclude them from priesthood - such exclusion being founded upon an anxiety that women might be able to reach greater spiritual heights than men.

By appropriating a female voice Breton can move closer to articulating penitence, but he cannot fully represent Pembroke's experience. Breton's admiration of the Psalms and anxiety about the value of his own writings could suggest that he realized that Pembroke's meditations demonstrated her ability to express as a writer that which for him was inexpressible.

\section{References}

Badir, Patricia. 2009. The Maudlin Impression. English Literary Images of Mary Magdalene 1550-1700. Notre Dame, Indiana: University of Notre Dame Press.

Breton, Nicholas. 1879. The Works in Verse and Prose. [Online]. Available: https://archive.org/details/worksinverseand02unkngoog [Accessed 2014, March 10].

Delany, Paul. 1969. British Autobiography in the $17^{\text {th }}$ Century. London: Routledge and Kegan Paul.

Duffy, Eamon. 2005 (1992). The Stripping of the Altars. Traditional Religion in England c. 1400-c.1580. $2^{\text {nd }}$ edition. New Haven and London: Yale University Press.

Foucault, Michel; Sennett, Richard. 1981. "Sexuality and Solitude" in London Review of Books, vol.3, no.9, 21 May-3 June.

Gouge, William. 1622. [Online]. Available: http://www.chapellibrary.org/pdf-other/otddu1.pdf. [Accessed 2014, August 21].

Harvey, Elizabeth D., 1992. Ventriloquized Voices: Female Theory and English Renaissance Texts. London: Routledge.

Irigaray, Luce. 1985. The Speculum of the Other Woman. Ithaca NY: Cornell University Press. Jansen, Katherine Ludwig. 2000. The Making of the Magdalen. Preaching and Popular Devotion in the Later Middle Ages. Princeton: Princeton University Press.

Lamb, Mary Ellen, 1990. Gender and Authorship in the Sidney Circle. Madison WI: University 
of Wisconsin Press.

Lauretis, Teresa de, 1989. Technologies of Gender: Essays on Theory, Film and Fiction Bloomington: Indiana University Press.

Moi, Toril. 1985. Sexual/Textual Politics: Feminist Literary Theory, London: Methuen.

Nora, Pierre. 1996. Realms of Memory: Rethinking the French Past. Lawrence D. Kritzman (Ed.). Transl. Arthur Goldhammer. New York: Columbia University Press.

Régnier-Bohler, Daniele. 1992. "Literary and Mystical Voices” in Klapisch-Zuber, Christiane. (Ed.). History of Women in the West. II. Silences of the Middle Ages. Cambridge, MA: Belknap Press of Harvard University Press (Duby, G and M. Perrot, general editors), pp. 428-482.

Schaus, Margaret C. (Ed.). 2006. Women and Gender in Mediaeval Europe: an Encyclopaedia. New York: Routledge.

Trill, Suzanne. 1998. "Engendering Penitence: Nicholas Breton and the 'Countesse of Penbrooke" in Voicing Women. Gender and Sexuality in Early Modern Writing. Kate Chedgzoy, Melanie Hansen and Suzanne Trill (Eds.). Edinburgh: Edinburgh University Press, pp. 25-44. 